\title{
Effect of sediment nearness on the metabolic enzyme activity and energy state of the oyster Crassostrea gigas
}

\author{
Gilles Le Moullac ${ }^{1, a}$, Pierre-Gildas Fleury ${ }^{3}$, Jean-René Le $\mathrm{Coz}^{2}$, Jeanne Moal ${ }^{2}$ and Jean-François Samain ${ }^{2}$ \\ 1 IFREMER, UMR 100 Physiologie et Ecophysiologie des Mollusques marins, Site Expérimental d'Argenton, 29840 Argenton en Landunvez, \\ France \\ 2 IFREMER, UMR 100 Physiologie et Ecophysiologie des Mollusques marins, Centre de Brest, BP 70, 29280 Plouzané, France \\ 3 IFREMER, Laboratoire Environnement-Ressources, 12 rue des Résistants, BP 26, 56470 La Trinité sur Mer, France
}

Received 27 June 2007; Accepted 2 October 2007

\begin{abstract}
This study was designed to assess in situ the effects of sediment nearness on Crassostrea gigas metabolism. One year-old oysters were reared for 5 months (April-August) in plastic bags on metallic frames at 10 and $60 \mathrm{~cm}$ off the sediment at the beginning of April. The management of the energetic resources (storage, consumption) was estimated with respect to biochemical changes of proteins, lipids and carbohydrates. In order to evaluate the effect of the sediment nearness at cellular level, the metabolic rate was evaluated by assessing pyruvate kinase (PK) and phosphoenolpyruvate carboxykinase (PEPCK) enzyme activities and electron transport system (ETS) activity. The metabolic pathways were assessed by measuring ATP and intermediary metabolites such as alanine, succinate and aspartate. Despite similar survival and growth at the two rearing levels, the protein, lipid and carbohydrate content were significantly lower in the oysters close to the bottom. In the oysters reared at $10 \mathrm{~cm}$, PK activity was also significantly reduced and a significant negative correlation between alanine content and PK activity was revealed. The sediment nearness decreased significantly the ATP content in the oyster. There was a significant relationship between ATP and aspartate in these oysters. The use of aspartate contributed to complete the metabolic pathways along with carbohydrate allowing to maintain the same biological performance as the oyster reared far from the bottom. The energy state (proteins, lipids, carbohydrates and ATP contents) could suggest that the oysters close to the sediment were fed less but the metabolic enzyme activities allow to suggest an oxygen deficiency. However, the reduced PK activity, the absence of PEPCK activity stimulation and the utilization of aspartate suggest a transition stage to anaerobiosis.
\end{abstract}

Key words: Oyster / Sediment / Metabolism / Proteins / Lipids / Carbohydrate / Alanine / Succinate / Aspartate

Résumé - Effet de la proximité du sédiment sur les activités enzymatiques métaboliques et l'état énergétique de l'huître Crassostrea gigas. Cette étude est conçue pour évaluer in situ les effets de la proximité du sédiment sur le métabolisme de l'huître Crassostrea gigas. Des huîtres âgées d'un an ont été élevées pendant 5 mois (avrilaoût) dans des poches grillagées en plastique posées sur des cadres métalliques à 10 et $60 \mathrm{~cm}$ du sédiment au début d'avril. La gestion des ressources énergétiques (stockage, consommation) est estimée par la mesure des protéines, des lipides et des glucides des huîtres entières. Afin d'estimer l'effet de la proximité de sédiment au niveau cellulaire, le flux métabolique est évalué par la mesure des activités enzymatiques de la pyruvate kinase (PK) et de la phopshoénolpyruvate carboxykinase (PEPCK) et l'activité du système de transport d'électron (ETS). Les voies métaboliques sont contrôlées en dosant les teneurs en ATP et les métabolites intermédiaires tels que l'alanine, le succinate et l'aspartate. Bien que les taux de survie et de croissance soient semblables aux deux niveaux d'élevage, les teneurs en protéines, lipides et glucides sont significativement plus faibles dans les huîtres élevées à $10 \mathrm{~cm}$. Chez les huîtres élevées à $10 \mathrm{~cm}$, l'activité de PK est significativement réduite et une corrélation négative significative entre le contenu d'alanine et l'activité de PK est révélée. La proximité du sédiment abaisse significativement le contenu en ATP. Un relation significative entre la teneur en ATP et l'aspartate est aussi mise en évidence. L'utilisation de l'aspartate apparaît donc comme une voie métabolique complémentaire de la glycolyse permettant de maintenir les mêmes performances biologiques que les huîtres éloignées du sédiment. Le statut énergétique défini par la teneur en protéines, lipides, glucides et ATP pourrait suggérer que les huîtres près du sédiment aient été moins nourries

\footnotetext{
a Corresponding author: Gilles.Le.Moullac@ifremer.fr
} 
mais les activités enzymatiques métaboliques laissent suggérer une insuffisance de l'oxygène. La réduction de l'activité de PK associée à la teneur en alanine, l'absence de stimulation de l'activité de PEPCK et l'utilisation de l'aspartate suggérent une étape de transition vers l'anaérobiose.

\section{Introduction}

Important mortality outbreaks have been reported in the Pacific oyster Crassostrea gigas populations on the French coasts 15 years in the past (Goulletquer et al. 1998; Soletchnik et al. 1999). The syndrome is known as summer mortality and generally associated with temperatures over $19^{\circ} \mathrm{C}$ and coincides with the period of sexual ripeness (Soletchnik et al. 1999, 2005). Some authors suggest that mortalities occurring in Pacific oyster are the result of multiple factors, including elevated temperature, physiological stress associated with gonadal maturation, aquaculture practices, pathogens and pollutants (Goulletquer et al. 1998; Samain et al. 2007). A seasonal cycle of storage and mobilization of energy reserves, especially glycogen was previously correlated with the annual reproductive cycle of bivalves (Berthelin et al. 2000). Indeed, glycogen content was positively associated with fecundity in oysters and negatively associated with gametogenic rate (Deslous-Paoli 1980). Glycogen content is also positively linked with survival of oysters during summer (Perdue et al. 1981; Berthelin et al. 2000).

Sediment is often hypoxic but the highest oxygen demand can be in the water close to the bottom (Diaz et Rosenberg 1995). Moreover, toxic substances like sulphides and ammonia in the sediment are generated under hypoxic conditions and their appearance is synchronous with the summer oyster mortality. The combined effects of hypoxia and sulfides on marine organism are difficult to separate (Vismann 1991). Nearness to the sedimentary has a drastic effect on oyster survival and growth (Soltechnik et al. 2005; Gagnaire et al. 2006). For the oyster $C$. gigas, the sediment nearness reduces the store of lipids and glycogen (Soltechnik et al. 2005). All these factors are responsible for the metabolic depression which results in the fall of ingestion and breathing. The reduction of feeding activity and oxygen consumption occurs in bivalves exposed to hypoxia and sulphide exposure (Sobral and Widdows 1997; Encomio 1998, Hicks and McMahon 2002). Metabolic depression in bivalves is achieved by a transition from aerobiosis to anaerobiosis (Shick et al. 1986; De Zwann et al. 1991; Encomio 1998; Laudien et al. 2002).

This study was designed to assess effects of sediment nearness on Crassostrea gigas metabolism. Oysters were reared at 10 and $60 \mathrm{~cm}$ above the sediment in plastic bags from April to August. Energetic resources were estimated with respect to changes of proteins, lipids and carbohydrates. In order to evaluate the effects of the sediment nearness at cellular level, the metabolic pathways were evaluated by assessing pyruvate kinase (PK) and phosphoenolpyruvate carboxykinase (PEPCK) enzyme activities and electron transport system (ETS) activity. The metabolic pathways were assessed by measuring ATP and the intermediary metabolites alanine, succinate and aspartate.

\section{Material and method}

\subsection{Experimental design and sampling}

Oyster used in this study were raised at Fort Espagnol, in the middle of Rivière d'Auray estuary in Southern Brittany. Temperature was measured twice a day at high tides. The oneyear wild oysters used in this study were collected in the Arcachon Basin. Bags containing 300 live oysters were put on iron frames at $10 \mathrm{~cm}$ and $60 \mathrm{~cm}$ off the bottom. At each sampling date, oysters were counted in one bag and shell measurements were recorded from 30 individuals. Dry meat weight was recorded after freeze-drying for $48 \mathrm{~h}$.

\subsection{Biochemical composition}

At each sampling date, whole-oyster soft tissue was dissected and combined in 3 pools of 10 animals each. The tissues were then frozen and stored in liquid nitrogen. Pooled tissues were ground with a Dangoumeau homogenizer. For total lipid, protein and carbohydrate analyses, $600 \mathrm{mg}$ of the wet homogenate was suspended with $3 \mathrm{ml}$ of distilled water and divided into three aliquots ( $200 \mu \mathrm{l}$ for carbohydrate and protein analysis and $400 \mu$ l for total lipid analysis). Total lipid contents were estimated according to Bligh and Dyer (1959) after extraction in a dichloromethane-ethanol-water mixture. The purified lipids were placed in a pre-weighed Teflon cup, dried under a nitrogen stream, and lipid content was estimated by weighing. Carbohydrate and protein contents were measured by colorimetry as described by Dubois et al. (1956) and Lowry et al. (1951), respectively. Results are expressed as milligrams of carbohydrate, lipid and protein per gram of wet weight.

\subsection{PK and PEPCK activities}

The activity of PK in oyster tissues was determined as described by Greenway and Storey (1999). Frozen tissues were prepared at a $1: 5 \mathrm{w} / \mathrm{v}$ ratio in a buffer composed of $50 \mathrm{mM}$ imidazole-HCl buffer (pH 7.2), $100 \mathrm{mM} \mathrm{NaF}, 5$ mM EDTA, $5 \mathrm{mM}$ EGTA and $15 \mathrm{mM}$ 2-mercaptoethanol. A few crystals of phenylmethylsulfonyl (PMSF) were added immediately prior to sonication. The homogenates were centrifuged for $20 \mathrm{~min}$ at $20000 \mathrm{~g}$ at $5{ }^{\circ} \mathrm{C}$. The assays were made in duplicate at room temperature and initiated by mixing the enzyme buffer with the $20 \mu \mathrm{l}$ homogenate in $250 \mu \mathrm{l}$ total microplate well volume. The preparation for pyruvate kinase (PK; EC 2.7.1.40) was as follows: $100 \mathrm{mM}$ imidazole-HCl buffer ( $\mathrm{pH} 7.2), 50 \mathrm{mM}$ $\mathrm{KCl}, 5 \mathrm{mM} \mathrm{MgCl} 2,10 \mathrm{mM}$ phosphoenolpyruvate, $2 \mathrm{mM}$ ADP, $0.15 \mathrm{mM} \mathrm{NADH}, 0.2 \% 2(\mathrm{v} / \mathrm{v})$ rotenone-saturated ethanol, and $1 \mathrm{U} \mathrm{ml}^{-1} \mathrm{LDH}$. For phosphoenolpyruvate carboxykinase (PEPCK; EC 4.1.1.32) the preparation was: $100 \mathrm{mM}$ imidazole-HCl buffer ( $\mathrm{pH}$ 6.6), $30 \mathrm{mM}$ 2-mercaptoethanol, $5 \mathrm{mM}$ phosphoenolpyruvate, $50 \mathrm{mM} \mathrm{NaHCO}_{3}, 1.25 \mathrm{mM}$ IDP, 
$1 \mathrm{mM} \mathrm{MnCl}_{2}, 0.15 \mathrm{mM}$ NADH, and $2.5 \mathrm{U} \mathrm{ml}^{-1} \mathrm{MDH}$. Blanks were run and subtracted. Changes in $\mathrm{NAD}(\mathrm{P}) \mathrm{H}$ absorbance at $340 \mathrm{~nm}$ were monitored using a Biotek microplate reader.

\subsection{Electron transport system activity}

ETS activity was determined following the method of Owens and King (1975), where INT-tetrazolium is reduced to INT-Formazan when substituted for oxygen as the terminal electron acceptor. Reagents were freshly made daily and kept on ice and all assay procedures were carried out in an ice bath. Frozen tissue powder was diluted in ETS B solution $\left(75 \mu \mathrm{M} \mathrm{MgSO}_{4} 7 \mathrm{H}_{2} \mathrm{O}, 1.5 \mathrm{mg} \mathrm{ml}^{-1}\right.$ polyvinylpyrrolidone, and $0.2 \%(\mathrm{v} / \mathrm{v})$ Triton X-100 in $0.1 \mathrm{M}$ phosphate buffer $\mathrm{pH}$ 8.5 ) and sonicated. Then samples were centrifuged for $15 \mathrm{~min}$ $\left(4{ }^{\circ} \mathrm{C}, 3000 \mathrm{~g}\right)$. One hundred fifty microliters supernatant was transferred to another tube containing $400 \mu \mathrm{l}$ substrate solution (1.2 $\mathrm{mg} \mathrm{ml}^{-1} \mathrm{NADH}, 0.2 \mathrm{mg} \mathrm{ml}^{-1} \mathrm{NADPH}$ in ETS B solution) and $250 \mathrm{ml}$ INT solution $\left(2 \mathrm{mg} \mathrm{ml}^{-1}\right.$ INT-tetrazolium in double distilled water $\mathrm{pH}$ 8.5). Samples were incubated for $20 \mathrm{~min}$ at room temperature after which the reaction was stopped with $400 \mu \mathrm{l}$ quench solution (50\% formalin, $50 \% 1 \mathrm{M} \mathrm{H}_{3} \mathrm{PO}_{4}$ ). The absorbance of each sample was then measured in duplicate spectrophotometrically at $490 \mathrm{~nm}$ using a Biotek microplate reader. The absorbance value was corrected by a blank, containing $150 \mu \mathrm{l}$ sample, $400 \mu \mathrm{l}$ ETS B, $250 \mu \mathrm{l}$ INT solution and $400 \mu \mathrm{l}$ quench solution. ETS $\left(\mu \mathrm{mol} \mathrm{O} \mathrm{h}^{-1} \mathrm{~g} \mathrm{ww}^{-1}\right)$ was then calculated by the following equation given by Garcia-Esquivel et al. (2001):

$$
\text { ETS }=\left(E_{\text {corr }} \times V_{\text {hom }} \times 60 / T \times V_{\text {rxn }}\right) /\left(V_{\text {inc }} \times w w \times 31.8\right)
$$

$E_{\text {corr }}=$ measured absorbance, corrected with the buffer and reagent blank, $V_{\text {hom }}=$ volume of the total homogenate $(\mathrm{ml})$, 60 = factor used for to express the activity per hour, $T=$ time of incubation $(\mathrm{min}), V_{\mathrm{rxn}}=$ final volume in the assay $(\mathrm{ml}), V_{\text {inc }}=$ volume of the homogenate used in the reaction assay (ml), ww: wet weight of the sample in the total homogenate $(\mathrm{g}), 31.8 E_{490 \mathrm{~nm}} \mathrm{~cm}^{-1}$ : the molar extinction coefficient of INT-formazan at $490 \mathrm{~nm}$ is $15.9 \mathrm{mM}_{I N T}^{-1} \mathrm{~cm}^{-1}$ assuming that 2 molecules of INT-formazan are formed per each mole of oxygen.

\subsection{Metabolite determination}

Metabolites and nucleotides were extracted from $200 \mathrm{mg}$ of the frozen oyster powder with $2 \mathrm{ml}$ of trichloroacetic acid (TCA), neutralized with $1.2 \mathrm{ml}$ of amine freon trioctylamine/trifluoro-trichloro-ethane, v:v, 1:5). ATP nucleotides were analysed by high-performance liquid chromatography on a reverse phase column with a counter-ion (tributylamine) according to Moal et al. (1989). Alanine and aspartate were measured enzymatically according to the procedure described by Williamson (1974) and Mollering (1985) respectively. Succinate was quantified with the succinate determination kits of R-Biopharm Inc (Marshall, MI, USA).

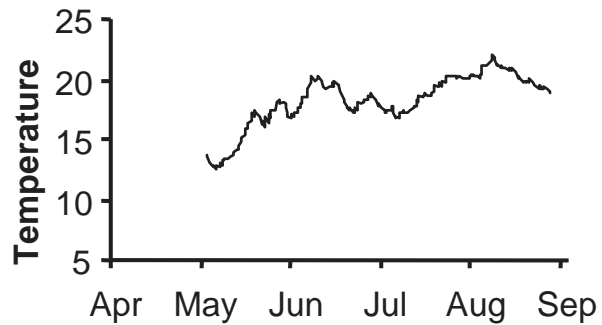

Fig. 1. Temperature variations during the experimental period.
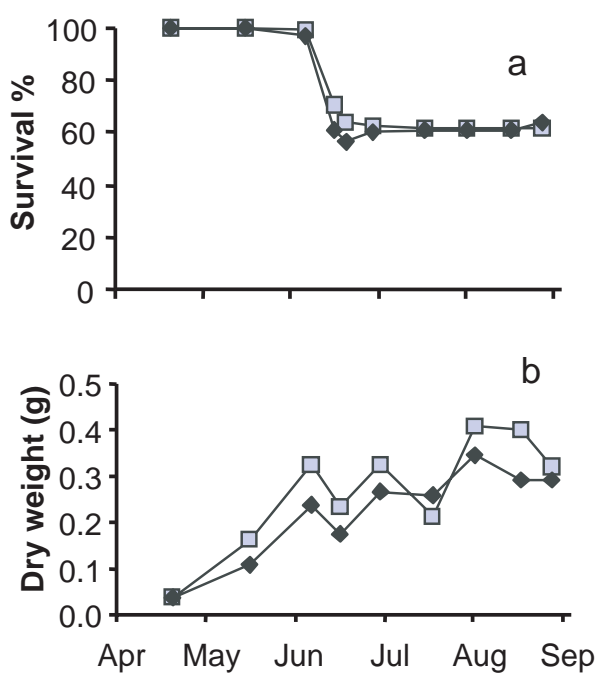

Fig. 2. (a) Survival and (b) growth of oyster according to the rearing height and sampling date. (grey) $60 \mathrm{~cm}$ and (black) $10 \mathrm{~cm}$.

\subsection{Statistics}

Two-way analysis of variance (ANOVA) was performed for biochemical and metabolic parameters to test the effect of sampling date and rearing level. Student's $t$-test was used as post-tests to compare the effect of the rearing level at specific sampling dates. Correlation between some variables was tested using the critical value table for Pearson's Correlation Coefficient; at the alpha level of $5 \%$ and $d f=17$, the null hypothesis was rejected when $r=0.456$. Statistical analyses were performed using Statview (SAS).

\section{Results}

\subsection{Biological performance}

This experiment was characterized by a mortality of $40 \%$ simultaneously on both rearing levels during the first fortnight of June (Fig. 1). Two weight loss episodes were observed in June and July; the first occurred during the first fortnight of June from the oysters reared at the two levels, and the second occurred on 19-July with the oysters reared at $60 \mathrm{~cm}$ off the bottom (Fig. 2). Mortality was simultaneous to the first weight loss when the temperature reached $19^{\circ} \mathrm{C}$. 

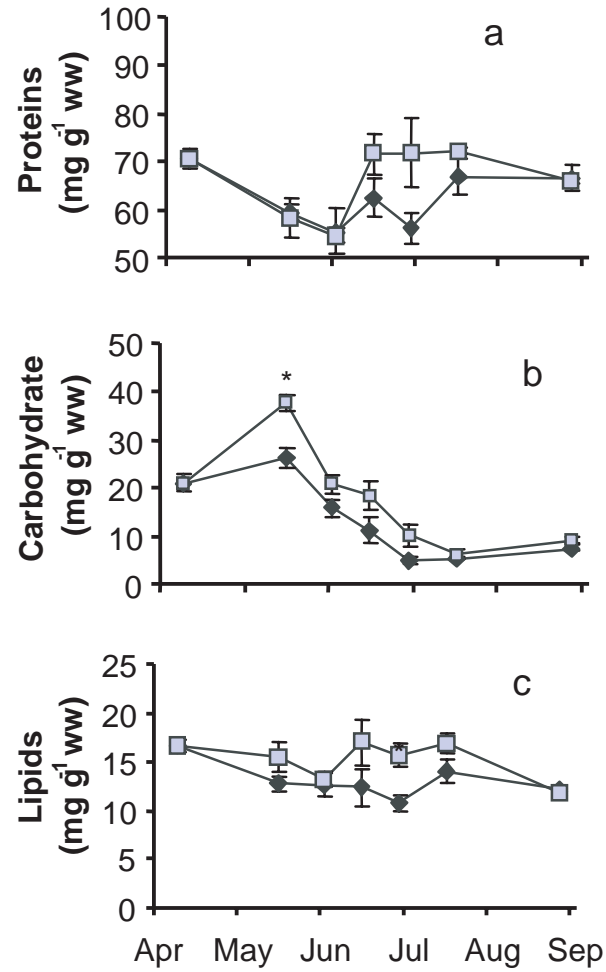

Fig. 3. The effects of rearing level and sampling date on proximal composition (a) proteins (b) lipids and (c) carbohydrate in Crassostrea gigas whole oyster. (grey) $60 \mathrm{~cm}$ and (black) $10 \mathrm{~cm}$. Results are means \pm SEM, $n=3 . *$, significant difference $(p<0.05$, Student $t$-test) between the rearing levels at each sampling day.

\subsection{Proximate composition of oyster tissue}

The variations in total protein in the oyster tissues are shown (Fig. 3a). The ANOVA revealed significant changes in total protein content according to the sampling date $(p<0.01)$ and the rearing level $(p<0.05)$ (Table 1$)$. The level of protein decreased from 9-April until 3-June in oyster at the two rearing level before to be restored on 17-June in the oyster reared at $60 \mathrm{~cm}$. The level of total protein was significantly lower in the oysters reared at $10 \mathrm{~cm}$ of the bottom.

Changes in carbohydrate content are plotted (Fig. 3b) showing significant changes according to the sampling date $(p<0.0001)$ and the rearing level $(p<0.0001)$ (Table 1$)$. Carbohydrate levels increased from 9-April to 17-May before declining until 17-June. Carbohydrate level was maximal on 17-May and significantly higher in oyster reared at $60 \mathrm{~cm}$ off the bottom (Fig. 3b). The level of carbohydrate was significantly lower in the oysters reared at $10 \mathrm{~cm}$ off the bottom from 17-May to 30-June. Lipid content changed significantly in the oyster tissues according to the sampling date $(p<0.01)$ and the rearing level $(p<0.01)$ (Fig. 3c, Table 1). Lipid levels were significantly lower in the oysters reared at $10 \mathrm{~cm}$ off the bottom.

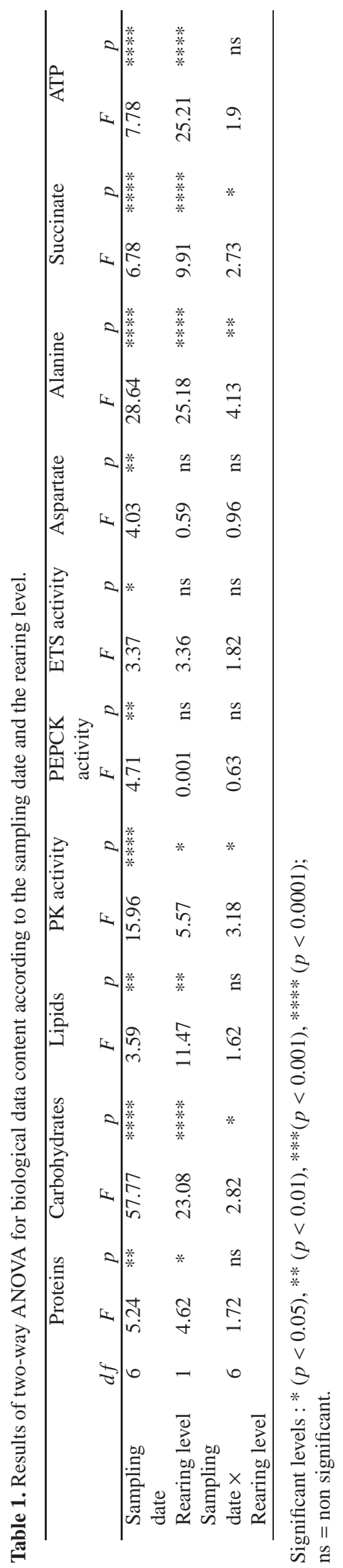



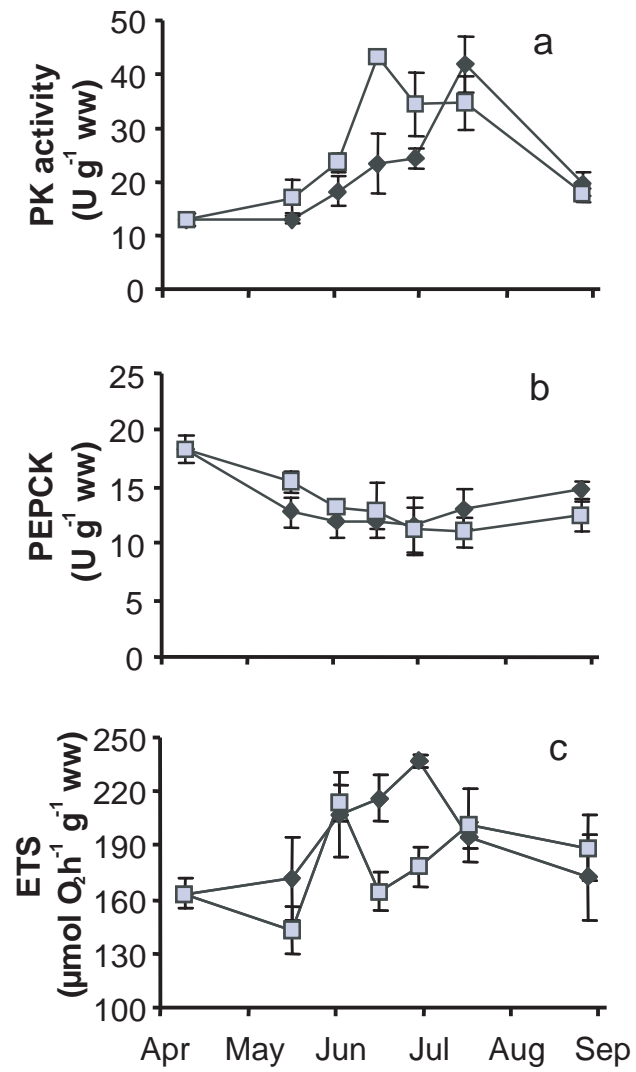

Fig. 4. The effects of rearing level and sampling date on (a) PK (b) PEPCK enzyme activity and (c) ETS activity in $C$. gigas whole oyster. (grey) $60 \mathrm{~cm}$ and (black) $10 \mathrm{~cm}$. Results are means \pm SEM, $n=3$. *, significant difference $(p<0.05$, Student $t$-test) between the rearing levels at each sampling day.

\subsection{PK, PEPCK and ETS enzyme activity}

Figure 4a displays PK enzyme activity in the oyster tissues as a function of sampling date. Two ways ANOVA revealed that PK enzyme activity changed according to the sampling date $(p<0.0001)$ and the rearing level $(p<0.05)$ (Table 1$)$. The PK enzyme activity increased significantly from 5-April until 17-June and 19-July in the oyster reared at $60 \mathrm{~cm}$ and $10 \mathrm{~cm}$ off the bottom, respectively. The PK enzyme activity was significantly lower in the oysters reared at $10 \mathrm{~cm}$ off the bottom. The PEPCK activity changed significantly according to the sampling date $(p<0.05)$ (Table 1$)$. The PEPCK enzyme activity was the highest in late spring (Fig. 4b). ETS activity (Fig. 4c) varied significantly with sampling date $(p<0.05)$ (Table 1).

\subsection{Metabolite content}

The aspartate content in oyster tissues changed significantly over time $(p<0.01)$ (Fig. 5a, Table 1). Alanine concentration varied significantly with the sampling date $(p<$ $0.0001)$ and the rearing level $(p<0.0001)$ (Table 1). The mean level of alanine was higher in oyster reared at $60 \mathrm{~cm}$
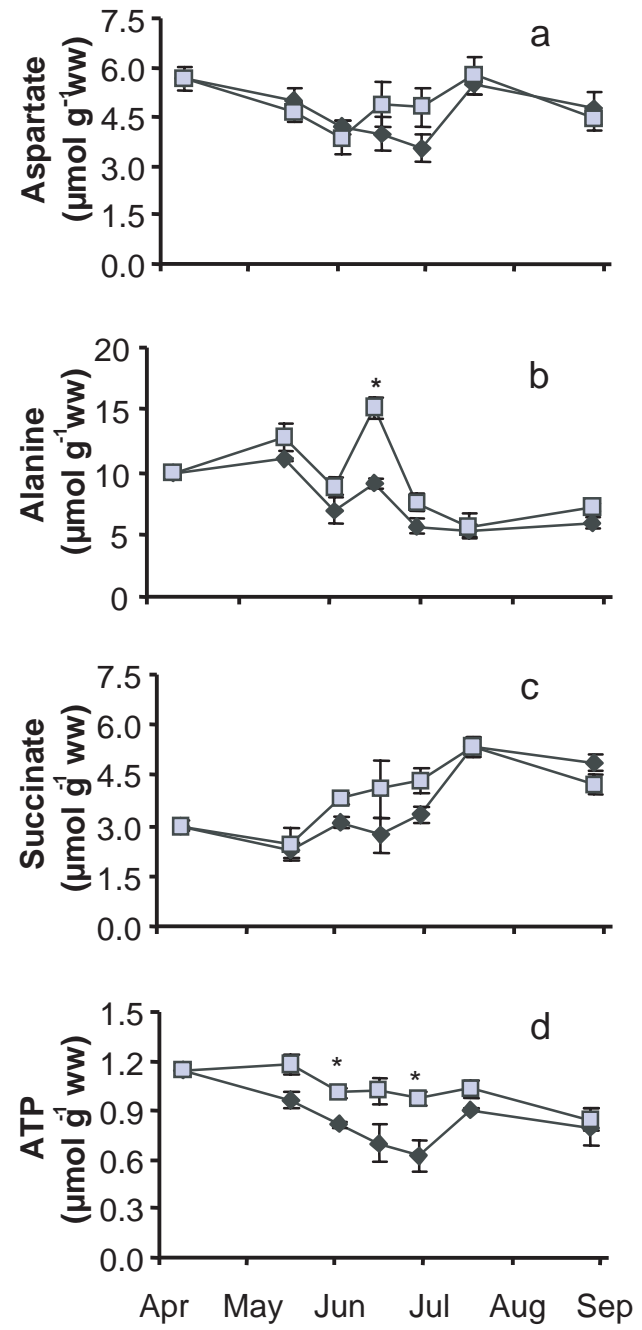

Fig. 5. The effects of rearing level and sampling date on (a) aspartate (b) alanine (c) succinate (d) ATP content in $C$. gigas whole oyster. (grey) $60 \mathrm{~cm}$ and (black) $10 \mathrm{~cm}$. Results are means \pm SEM, $n=3$. *, significant difference ( $p<0.05$, Student $t$-test) between the rearing levels at each sampling day.

off the bottom (Fig. 5b). Succinate content changed according to the sampling date $(p<0.001)$ and the rearing level $(p<0.01)$ (Table 1). Succinate was significantly higher in offbottom oyster (Fig. 5c).

The ATP content changed significantly with both sampling date $(p<0.0001)$ and the rearing level $(p<0.0001)$ (Table 1$)$. The level of ATP decreased significantly from the 9-April to 1July in oyster reared at $10 \mathrm{~cm}$ off the bottom and the mean level of ATP was lower in oyster reared at $10 \mathrm{~cm}$ off the bottom. On 19-July, the ATP content in on bottom oyster increased close to those in the $60 \mathrm{~cm}$ off bottom oysters (Fig. $5 \mathrm{~d}$ ).

PK was inversely correlated with alanine concentration in oysters at $10 \mathrm{~cm}$. For the oysters reared at $10 \mathrm{~cm}$ off the bottom the relationship between alanine and PK activity was significant, the Pearson correlation coefficient was $\mathrm{r}=-0.510$ $(d f=17, p<0.05)$.

Aspartate content was highly correlated to ATP, the Pearson correlation coefficient was $r=0.77(d f=17, p<0.05)$. 


\section{Discussion}

\subsection{Effect of temporal changes}

Summer mortalities of oyster occur most often when temperatures reach $19{ }^{\circ} \mathrm{C}$ for the first time during the reproductive process of oysters (Soletchnik et al. 2006). In our experiment, the episode of mortality coincided with the temperature reaching $19{ }^{\circ} \mathrm{C}$ and with a weight loss of oysters. One hypothesis to explain the weight loss of oysters would be the mortality of large ripe oysters. Alternatively, it could be represent a spawning episode.

Limited glycogen content has often been associated with mortality events (Mori 1979; Perdue et al. 1981). Mori et al. (1965) and Mori (1979) linked oyster mortality event at eutrophic environment considering that low carbohydrate content and high gonad development are combined factors increasing the mortality risk. In the present study, mortality occurred in early June when carbohydrate content was still high in the oysters of both rearing levels. Protein content of the oysters decreased during the first two months (April-May) but recovered later in the year. Glycogen stores increased until April. The mortality occurring in early June was not linked to low carbohydrate content. The decrease of carbohydrate in the oyster tissues corresponded to the mobilization of glycogen during the vitellogenesis process (Berthelin et al. 2000) and muscle needs (Dunphy et al. 2006). Significant changes in lipid content were observed but are small compared to drastic increases during gametogenesis observed in another study (Soletchnik et al. 2006).

The PK activity in the oyster $C$. gigas seemed linked to seasonal changes and to the reproductive process. As in some other invertebrates, the oyster Crassostrea virginica (Greenway and Storey 1999, 2000), the periwinkle Littorina littorea (Greenway and Storey 2001), the horse mussel Modiolus modiolus (Lesser and Kruse 2004), the PK activity in $C$. gigas is subjected to season. During the gametogenesis which is held in spring, the PK activity increased; then with the end of this process corresponding to the major spawning in summer, the PK activity decreased. Part of the seasonal effect on the PK activity could be due to temperature by changing the kinetic properties. In summer the affinity of PK for PEP may decrease and the sensitivity to alanine inhibition increase due to the changing isoenzyme pattern of PK (Greenway and Storey 2000). The changes of the PEPCK activity in oyster during this experiment did not seem linked to season. In Littorina littorea, changes are tissue specific, Greenway and Storey (2001) observed significant changes of PEPCK enzyme activity only in the digestive gland between winter and summer but not in the foot muscle. So the absence of variations of PEPCK in our study may be related to the mixing of tissues.

The changes of ETS activity along the experimental period resulted of numerous factors. In the oyster $C$. gigas, ETS activity is closely related to temperature (Le Moullac et al. 2007, in press). These relationships were already shown in other bivalves (Madon et al. 1998; Fanslow et al. 2001). Besides the regulation by temperature, ETS is submitted to feeding (Garcia Esquivel et al. 2002) and pH (Simcic and Brancelj 2006).

\subsection{Effect of the rearing level}

Previous studies in the Marennes-Oléron Bay (Charente Maritime, France) have shown a drastic effect of nearness to bottom on oyster survival, growth and glycogen storage (Soletchnik et al. 1999, 2005). In our study, the rearing level induced differences in protein, lipid and carbohydrate contents that were lower in oyster reared at $10 \mathrm{~cm}$ than in the oyster reared at $60 \mathrm{~cm}$ off the bottom. For protein, the effect of rearing level occurred after the mortality event. But for carbohydrates and lipids, the difference appeared during the first month of experiment while carbohydrates were being stored. Experimentally, Delaporte et al. (2006) have shown that the biochemical composition of oysters was related to the food level. Differences in carbohydrate and lipid storage were also observed in situ according to the sediment nearness (Soletchnik et al. 2005). We therefore suggest that the oyster reared close to the sediment fed less than those reared farther from the sediment. Reduced ingestion could be related either to differences in food availability or to metabolic depression due to noxious compounds diffusing from the sediment in the water column.

From mid May until the end of June corresponding to the reproductive process, the PK activity and the ATP level in the oysters reared close to the bottom were lower than in oyster farther from the sediment. The nearness of the sediment affected the metabolic pathways of energy production involving a differential regulation of PK enzyme. The molecular basis of $\mathrm{PK}$ regulation in response to lack of oxygen is well known and similar in many species of marine molluscs (Plaxton and Storey 1984; Simpfendörfer et al. 1997; Storey 1993; Greenway and Storey 2000; Greenway and Storey 2001): phosphorylation of PK reduces its affinity for PEP, reduces its sensitivity to the allosteric activator fructose-1,6-biphosphate $(\mathrm{F} 1,6 \mathrm{BP})$ and greatly enhances enzyme inhibition by alanine. A negative relationship between PK and alanine was observed only in the oysters reared close to the bottom may indicate that PK of these oysters was more sensitive to alanine. When PK activity is inhibited in hypoxia, PEP is converted to oxaloacetate by PEPCK and ultimately in succinate accumulation (de Zwann and Mathieu 1992). In this experiment, the PEPCK activities were not elevated in the oysters close to the bottom and succinate did not accumulate. The oysters reared close to the sediment could have triggered an additional pathway based on the utilisation of aspartate to produce ATP. This pathway of energy production along with carbohydrate can complement a response to oxygen depletion (de Zwann 1983). In a simultaneous carbohydrate and aspartate degradation, all metabolic pathways show specific alteration leading to a low ATP production. This metabolic situation should be transitory since it is an immediate response to oxygen depletion (de Zwann and Mathieu 1992). In the present experimentation, this metabolic behavior spanned the whole month of June.

The ETS activity measures the activity of the chain of transport of electrons (Madon et al. 1998; Fanslow et al. 2001). During the present study, the activity of the electron transport system (ETS) was episodically stimulated in oysters reared close to the bottom. And although the oxygen level was not measured, the response of ETS could be due to hypoxic events; hypoxia stimulated ETS activity in the oyster $C$. gigas 
(Le Moullac et al. in press). The stimulation of the ETS activity in hypoxic oyster could probably be linked to some upregulated genes of the respiratory chain as in anoxia tolerant organisms such as the cytochrome c oxidase III and NADH dehydrogenase 3, 4, 5 and 6 were recently identified after 7-10 days of hypoxia exposure in C. gigas (David et al. 2005). Despite the increase of ETS activity in oyster reared close to the bottom, the ATP level was the lowest.

This study showed that the metabolism of oysters reared close to the sediment was altered involving oysters in a metabolic depression. The energy state (proteins, lipids, carbohydrates, ATP) could suggest that the oysters close to the sediment were fed less but depressed metabolic enzyme activities suggest an oxygen deficiency. According to De Zwann and Mathieu (1992), the reduced PK activity, the absence of PEPCK activity stimulation and the utilization of aspartate represent a transition stage to anaerobiosis. An alternate pathway of energy production based on the use of the aspartate as fuel would be established resulting in a low ATP production. Oxygen and the sedimentary compounds like ammonium and sulphides were not measured, however each separately or in combination can be involved in depression of metabolism.

Acknowledgements. This work was supported by the Morest national project funded by Ifremer, the Régions de Basse Normandie, Bretagne, Pays de Loire and Poitou-Charentes and the Conseil Général du Calvados. Our thanks also to Michel Mathieu, director of the UMR 100, Physiologie et Ecophysiologie des Mollusques marins.

\section{References}

Berthelin C., Kellner K., Mathieu M., 2000, Storage metabolism in the Pacific oyster (Crassostrea gigas) in relation to summer mortalities and reproductive cycle (west coast of France). Comp. Biochem. Physiol. 125, 359-369.

Bligh E.G., Dyer W.J., 1959, A rapid method for total lipid extraction and purification. Can. J. Biochem. Physiol. 37, 911-917.

David E., Tanguy A., Pichavant K., Moraga D., 2005, Response of the Pacific oyster Crassostrea gigas to hypoxia exposure under experimental conditions. FEBS J. 272, 5635-5652.

de Zwann A., 1983, Carbohydrate catabolism in bivalves. In: Hochacka P.W. (Ed.) The Mollusca (vol. 1) Metabolic biochemistry and molecular biomechanics. Academic Press, NY, pp. 137175.

de Zwann A., Cortesi P., van den Thillart G., Roos J., Storey K.B., 1991, Differential sensitivities to hypoxia by two anoxia tolerant marine molluscs: a biochemical analysis. Mar. Biol. 111, 343351.

de Zwann A., Mathieu M., 1992, Cellular Biochemistry and endocrinology. In: Gosling E. (Ed.) The mussel mytilus: ecology, physiology, genetics and culture. Elsevier, Amsterdam, pp. 223293.

Delaporte M., Soudant P., Lambert C., Moal J., Pouvreau S., Samain J.F., 2006, Impact of food availability on energetic storage and defense related hemocyte parameters of the Pacific oyster Crassostrea gigas during an experimental reproductive cycle. Aquaculture 254, 571-582

Deslous-Paoli J.M., 1980. Contribution à l'étude de la biologie de l'huître C.gigas Thunberg dans le bassin et les claires de Marennes-Oléron. Thèse de 3ème cycle, Université d'AixMarseille II.

Diaz R.J., Rosenberg R., 1995, Marine benthic hypoxia: a review of its ecological effects and the behavioural responses of benthic macrofauna. Ocean. Mar. Biol.: Annual Review 33, 245-303.

Dubois M., Gilles K.A., Hamilton J.K., Rebers P.A., Smith F., 1956, Colorimetric method for determination of sugars and related substances. Anal. Chem. 28, 350-356.

Dunphy B.J., Wells R.M.G., Jeffs A.G., 2006, Oxygen consumption and enzyme activity of the subtidal flat oyster (Ostrea chilensis) and Pacific oyster (Crassostrea gigas): responses to temperature and starvation. NZ J. Mar. Freshwater Res. 40, 149-158.

Encomio V.G., 1998, Respiratory and metabolic response to sulfide and hypoxia in the marine echiuran worm, Urechis caupo. San Francisco University, PhD Thesis.

Fanslow D.L., Nalepa T.F., Johengen T.H., 2001, Seasonal changes in the respiratory electron transport system (ETS) and respiration of the zebra mussel, Dreissena polymorpha in Saginaw Bay, lake Huron.. Hydrobiologia 448, 61-70.

Gagnaire B., Soletchnik P., Madec P., Geairon P., Le Moine O., Renault T., 2006, Diploid and triploid Pacific oysters, Crassostrea gigas (Thunberg), reared at two heights above sediment in Marennes-Oléron Basin, France; Difference in mortality, sexual maturation and hemocyte parameters. Aquaculture 254, 606-616.

Garcia-Esquivel Z., Bricelj V.M., Gonzalez-Gomez M.A., 2001, Physiological basis for energy demands and early postlarval mortality in the Pacific oyster, Crassostrea gigas. J. Exp. Mar. Biol. Ecol. 263, 77-103.

Garcia-Esquivel Z., Bricelj V.M., Felbeck H., 2002, Metabolic depression and whole-body response to enforced starvation by Crassostrea gigas postlarvae. Comp. Biochem. Physiol. 133A, 63-77

Goulletquer P., Soletchnik P., Le Moine O., Razet D., Geairon P., Faury N., Taillade S., 1998, Summer mortality of the Pacific cupped oyster Crassostrea gigas in the Bay of Marennes-Oléron (France). Cons. int. Explor. Mer, CM 1998 / CC 14.

Greenway S.C., Storey K.B., 1999, The effect of prolonged anoxia on enzyme activities in oysters (Crassostrea virginica) at different seasons. J. Exp. Mar. Biol. Ecol. 242, 259-272.

Greenway S.C., Storey K.B., 2000, Seasonal change and prolonged anoxia affect the kinetic properties of phosphofructokinase and pyruvate kinase in oysters. J. Comp. Physiol. B 170, 285-293.

Greenway S.C., Storey K.B., 2001, Effects of seasonal change and prolonged anoxia on metabolic enzymes of Littorina littorea. Can. J. Zool. 79, 907-915.

Hicks D.W., McMahon R.F., 2002, Respiratory responses to temperature and hypoxia in the nonindigenous brown mussel, Perna perna (Bivalvia: Mytilidae), from the Gulf of Mexico. J. Exp. Mar. Biol. Ecol. 277, 61-78.

Laudien J., Schieck D., Brey T., Portner H.O., Arntz W.E., 2002, Survivorship of juvenile clams Donax serra (Bivalvia, Donacidae) exposed to severe hypoxia and hydrogen sulphide. J. Exp. Mar. Biol. Ecol. 271, 9-23.

Le Moullac G., Bacca H., Huvet A., Moal J., Pouvreau S., Van Wormhoudt A., 2007, Transcriptional regulation of pyruvate kinase and phosphoenolpyruvate carboxykinase in the adductor muscle of the oyster Crassostrea gigas during prolonged hypoxia. J. Exp. Zool. 307A, 371-382. 
Le Moullac G., Quéau I., Le Souchu P., Pouvreau S., Moal J., Le Coz J.R., Samain J.F., 2007, Metabolic adjustments in the oyster Crassostrea gigas according to oxygen level and temperature. Mar. Biol. Res. in press.

Lesser M.P., Kruse V.A., 2004, Seasonal temperature compensation in the horse mussel, Modiolus modiolus: metabolic enzymes, oxidative stress and heat shock proteins. Comp. Biochem. Physiol. 137A, 495-504.

Lowry O.H., Rosenbrough N., Farr A.L., Randall R.J., 1951, Protein measurement with Folin phenol reagent. J. Biol. Chem. 193, 265275.

Madon S.P., Schneider D., Stoeckel J.A., 1998, In situ estimation of zebra mussel metabolic rates using the electron transport system (ETS) assay. J. Shellfish Res. 17, 195-203.

Moal J., Le Coz J.R., Samain J.F., Daniel J.Y., 1989, Nucleotides in bivalves: extraction and analysis by high -performance liquid chromatography (HPLC). Comp. Biochem. Physiol., 93B, 307316.

Mollering H., 1985, L-Aspartate and L-asparagine. In: Bergmeyer H.U. (Ed.) Methods in Enzymatic Analysis. $8 \mathrm{~N}^{\circ} 3$. Verlag Chemie, Weinheim, pp. 350-357.

Mori K., Tamate H., Imai T., Itikawa O., 1965, Changes in the metabolism of lipids and glycogen of the oyster during the stages of sexual maturation and spawning. Bull. Tohoku Reg. Fish. Res. Lab. 25, 65-88.

Mori K., 1979, Effects of artificial eutrophication on the metabolism of the Japanese oyster Crassostrea gigas. Mar. Biol. 53, 361-369.

Owens T.G., King F.D., 1975, The measurement of respiratory electron transport system activity in marine zooplankton. Mar. Biol. 30, 27-36.

Perdue J.A., Beattie J.H., Chew K.K., 1981, Some relationships between gametogenic cycle and summer mortality phenomenon in the pacific oyster (Crassostrea gigas) in Washington State. J. Shellfish Res. 1, 9-16.

Plaxton W.C., Storey K.B., 1984, Purification and properties of aerobic and anoxic forms of pyruvate kinase from red muscle organ of the channeled whelk, Busycotypus canaliculatum. Eur. J. Biochem. 143, 257-265.

Samain J.F., Dégremont L., Soletchnik P., Haure J., Bédier E., Ropert M., Moal J., Huvet A., Bacca H., Van Wormhoudt A., et al., 2007, Genetically based resistance to summer mortality in the
Pacific oyster (Crassostrea gigas) and its relationship with physiological, immunological characteristics and infection processes. Aquaculture 268, 227-243.

Simcic T., Brandcelj A., 2006, Effects of $\mathrm{pH}$ on electron transport system (ETS) activity and oxygen consumption in Gammarus fossarum, Asellus aquaticus and Niphargus sphagnicolus. Freshwater Biol. 51, 686-694.

Shick J.M., Gnaiger E., Widdows J., Bayne B.L., de Zwann A., 1986, Activity and metabolism in the mussel Mytilus edulis L. during intertidal hypoxia and aerobic recovery. Physiol. Zool. 59, 627642.

Simpfendörfer R.W., Vial M.V., Monsalve A., 1997, The adductor muscle pyruvate kinase from the intertidal bivalve Mytilus chilensis (Hupé): evidence of the presence of a phosphorylated form of the enzyme during the entire tidal cycle. J. Exp. Mar. Biol. Ecol. 213, 169-179.

Sobral P., Widdows J., 1997, Influence of hypoxia and anoxia on the physiological responses of the clam Ruditapes decussatus from southern Portugal. Mar. Biol. 127, 455-461.

Soletchnik P., Le Moine O., Faury N., Razet D., Geairon P., Goulletquer P., 1999, Summer mortality of the oyster in the Bay Marennes-Oléron: Spatial variability of environment and biology using a geographical information system (GIS). Aquat. Living Resour. 12, 131-143.

Soletchnik P., Lambert C., Costil K., 2005, Summer mortality of Crassostrea gigas (Thunberg) in relation to environmental rearing conditions. J. Shellfish Res. 24, 197-207.

Soletchnik P., Faury N., Goulletquer P., 2006, Seasonal changes in carbohydrate metabolism and its relationship with summer mortality of Pacific oyster Crassostrea gigas (Thunberg) in Marennes-Oléron bay (France). Aquaculture 252, 328-338.

Storey K.B., 1993, Molecular mechanism of metabolic arrest in molluscs. In: Hochachka P.W., Lutz P.L., Sick T., Rosenthal M., van den Thillart G. (Eds.) Surviving Hypoxia : Mechanisms of Control and Adaptation. CRC Press; Boca Raton; pp. 253-269.

Vismann B., 1991, Sulfide tolerance: Physiological mechanisms and ecological implications. Ophelia 34, 1-27.

Williamson D.H., 1974, Determination with alanine dehydrogenase. In: Bergmeyer H.U. (Ed.), Methods of Enzymatic Analysis. Vol. 2. Academic Press, New York, pp.1679-1682. 